\title{
Erratum: Editors' Message: Online re-publication of legacy articles on the occasion of Hydrogeology Journal's 20th anniversary, 1992-2012, and Editors' Message: Eminent hydrogeologists profiled in 20 years of Hydrogeology Journal (1992-2012)
}

\author{
Clifford I. Voss • Sue M. Duncan
}

Erratum to: Hydrogeology Journal (2012) 20: 1433-1439 DOI 10.1007/s10040-012-0928-1

Erratum to: Hydrogeology Journal (2013) DOI 10.1007/s10040-013-1009-9

Keywords Hydrogeology Journal · History of Hydrogeology Journal · Profiles of eminent hydrogeologists · Valery Mironenko

In celebration of Hydrogeology Journal's $(H J)$ 20th anniversary, the editorial team and the journal's publisher, Springer-Verlag, gathered together legacy articles that existed only in old printed issues and republished them online, either amongst the online volumes or as electronic supplementary material (ESM) associated with Voss and Duncan (2012). The end result of this lengthy process was a useful itemisation of legacy editorial messages, prefaces, reports, comments and replies, publication notes, errata, and profiles of eminent hydrogeologists.

Published online: 22 September 2013

(C) Springer-Verlag Berlin Heidelberg 2013

The online version of the original articles can be found at http://dx.doi.org/ 10.1007/s10040-012-0928-1 and http://dx.doi.org/10.1007/s10040-013$1009-9$.

Electronic supplementary material The online version of this article (doi:10.1007/s10040-013-1047-3) contains supplementary material, which is available to authorized users.

C. I. Voss ( $)$

US Geological Survey, 345 Middlefield Rd,

MS 496, Menlo Park, CA 94025, USA

e-mail: cvoss@usgs.gov

S. M. Duncan

International Association of Hydrogeologists,

PO Box 4130, Goring, Reading, RG8 6BJ, UK

e-mail: sduncan@iah.org
The process spawned a further editorial message that listed all eminent hydrogeologists profiled in $H J$ during its first 20 years (Duncan and Voss 2013). It was later discovered, however, that a profile about Valery Mironenko (Zaltsberg 2000) was missing from the online cohort, and this prompted the discovery of further editorial messages that had somehow slipped through the net.

It was decided that the opportunity had already passed to publish these missing articles online and to insert them into the correct $H J$ volumes, and so they are supplied as ESM with this erratum. Appropriate additions to the tables in Voss and Duncan (2012) and Duncan and Voss (2013) are given below.

For readers interested in profiles of eminent hydrogeologists, an opportunity arises here to highlight one of the already published articles, which summarises the most influential work of the US Geological Survey and other organisations and individuals around the world from the 1880s onwards (Back and Herman 1997). 

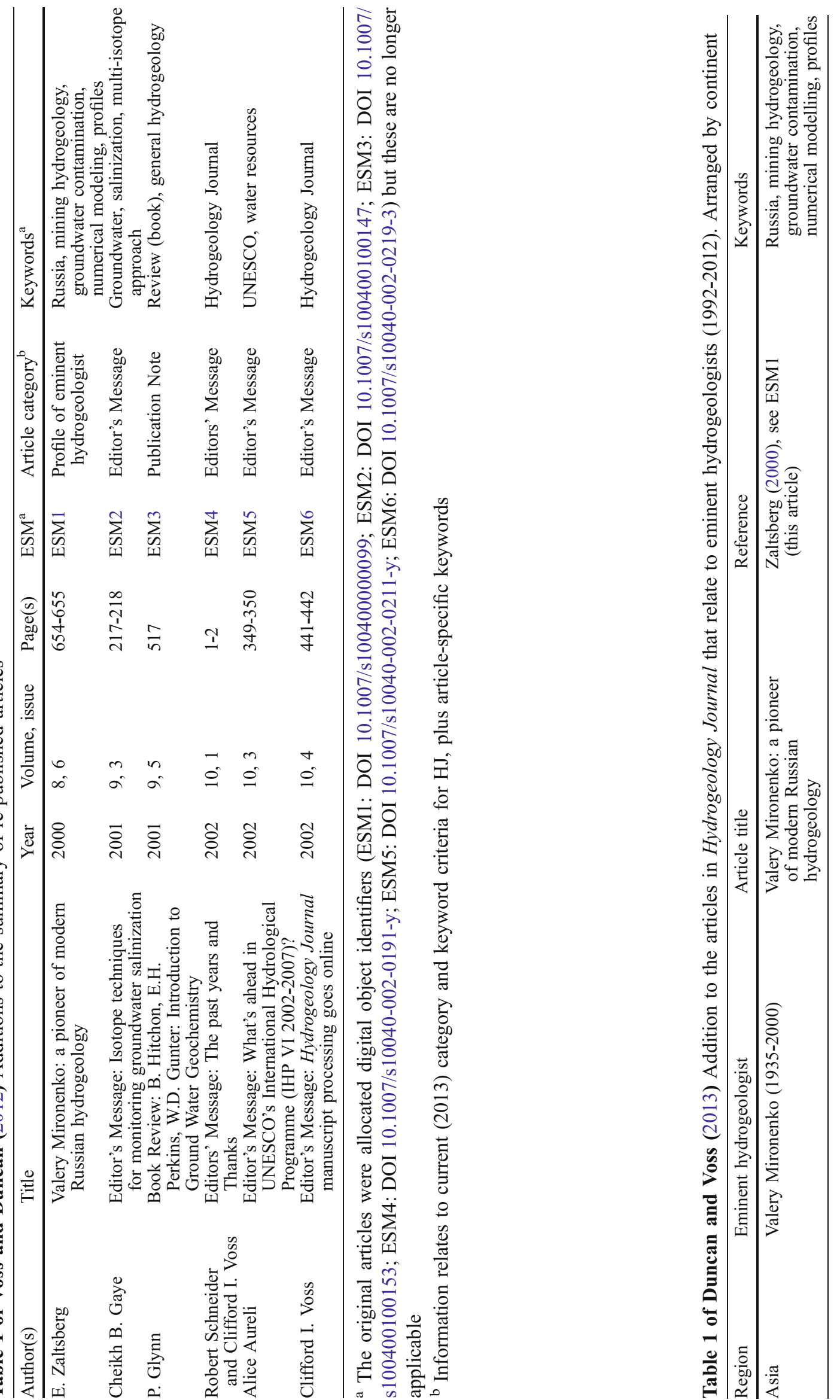


\section{References}

Back W, Herman JS (1997) American Hydrogeology at the Millennium: An Annotated Chronology of 100 Most Influential Papers. Hydrogeology Journal 5(4):37-50. doi:10.1007/ s100400050255

Duncan SM, Voss CI (2013) Editors' Message: Eminent hydrogeologists profiled in 20 years of Hydrogeology Journal
(1992-2012). Hydrogeology Journal. doi:10.1007/s10040-0131009-9

Voss CI, Duncan SM (2012) Editors' Message: Online republication of legacy articles on the occasion of Hydrogeology Journal's 20th anniversary, 1992-2012. Hydrogeology Journal 20:1433-1439. doi:10.1007/s10040-012-0928-1

Zaltsberg E (2000) Valery Mironenko: a pioneer of modern Russian hydrogeology. Hydrogeology Journal 8:654-655 